\title{
The costs of not training : contribution for the Netherlands
}

Citation for published version (APA):

de Grip, A., Heijke, J. A. M., \& Willems, E. J. T. A. (1992). The costs of not training : contribution for the Netherlands. Researchcentrum voor Onderwijs en Arbeidsmarkt, Faculteit der Economische

Wetenschappen. ROA Working Papers No. 7E https://doi.org/10.26481/umarow.199207E

Document status and date:

Published: 01/01/1992

DOI:

10.26481/umarow.199207E

Document Version:

Publisher's PDF, also known as Version of record

\section{Please check the document version of this publication:}

- A submitted manuscript is the version of the article upon submission and before peer-review. There can be important differences between the submitted version and the official published version of record.

People interested in the research are advised to contact the author for the final version of the publication, or visit the DOI to the publisher's website.

- The final author version and the galley proof are versions of the publication after peer review.

- The final published version features the final layout of the paper including the volume, issue and page numbers.

Link to publication

\footnotetext{
General rights rights.

- You may freely distribute the URL identifying the publication in the public portal. please follow below link for the End User Agreement:

www.umlib.nl/taverne-license

Take down policy

If you believe that this document breaches copyright please contact us at:

repository@maastrichtuniversity.nl

providing details and we will investigate your claim.
}

Copyright and moral rights for the publications made accessible in the public portal are retained by the authors and/or other copyright owners and it is a condition of accessing publications that users recognise and abide by the legal requirements associated with these

- Users may download and print one copy of any publication from the public portal for the purpose of private study or research.

- You may not further distribute the material or use it for any profit-making activity or commercial gain

If the publication is distributed under the terms of Article $25 \mathrm{fa}$ of the Dutch Copyright Act, indicated by the "Taverne" license above, 
THE COSTS OF NOT TRAINING.

CONTRIBUTION FOR THE NETHERLANDS

ROA-W-1992/7E

A. de Grip, J.A.M. Heijke, E.J.T.A. Willems

RESEARCH CENTRE FOR EDUCATION AND THE LABOUR MARKET

Faculty of Economics and Business Administration

Rijksuniversiteit Limburg

Maastricht, December 1992 
CIP-GEGEVENS KONINKLIJKE BIBLIOTHEEK, DEN HAAG

Grip, A. de

The costs of not training. Contribution for the Netherlands / A. de Grip, J.A.M. Heijke, E.J.T.A. Willems. - Maastricht : Research Centre for Education and the Labour Market, Faculty of Economics and Business Administration, Rijksuniversiteit Limburg. - (ROA-W-1992/7E)

Met lit. opg.

ISBN 90-5321-094-6

Trefw.: onderwijs en arbeidsmarkt ; Nederland. 
CONTENTS

Page

ABSTRACT

1. SKILL STRUCTURE AND TRAINING LEVELS

2. FORECASTS OF THE LABOUR MARKET AND THE USE OF LABOUR MARKET MODELS

3. TRAINING ACTIVITIES

4. SOME CONCLUSIONS

REFERENCES 


\section{ABSTRACT}

In this paper, we will make an inventory of the most relevant Dutch studies which may be helpful for the EC research project on 'The Costs of Not Training' carried out on behalf of the Task Force on Human Resources, Education, Training and Youth. The paper is divided into four sections: (1) the skill structure and training levels, (2) forecasts of the future labour market and the use of labour market models, (3) training activities and (4) some conclusions. 


\section{SKILL STRUCTURE AND TRAINING LEVELS}

The most important source of data for labour market research at a reasonably detailed level is the Labour Force Survey (Dutch abbreviation EBB, Enquête BeroepsBevolking), which is conducted by the Dutch Central Bureau of Statistics (CBS). This survey began in 1987, following on from the Labour Force Census (Dutch abbreviation AKT, ArbeidsKrachtenTelling), which was held biannually from 1973 to 1985 . The EBB survey is made among 132,000 persons, at least 14 years old, living in private households in the Netherlands. The results are published annually.

The EBB contains, among other things, data on the occupational structure of employment, in which the occupations are, apart from some small deviations, classified according to the International Standard Classification of Occupations (ISCO). Data on the skill structure of the working population has only been available since 1989 (at a high level of aggregation) or 1990 (at a more detailed level). The education variable is classified according to the International Standard Classification of Educations (ISCED). Tables 1 and 2 present the occupational and the educational structure of employment, respectively. These tables can be further differentiated by economic sector of industry.

De Grip has published some articles on 'Occupational Winners and Losers on the Labour Market' (see De Grip, 1986, De Grip, 1987, and De Grip and Dekker, 1993), based on the AKT and EBB data. In these articles he signals the most important shifts in the occupational structure of employment. Furthermore, using shift-share analyses, he examines the shifts in the educational structure in relation to occupational developments.

Thus far we have mentioned only statistics on the employment structure. However, the CBS also registers figures on unemployment and the number of vacancies. The unemployment statistics are based on the EBB, mentioned above, and on the number of unemployed who have signed on at the Labour Exchanges. The statistics on the number of vacancies, based on a survey among firms, allow the number of vacancies which are hard to fulfil to be seperated out. See tables 3 and 4 for the unemployment rate and the vacancy rate by level of education. 
Table 1. Working population by occupational class 1991

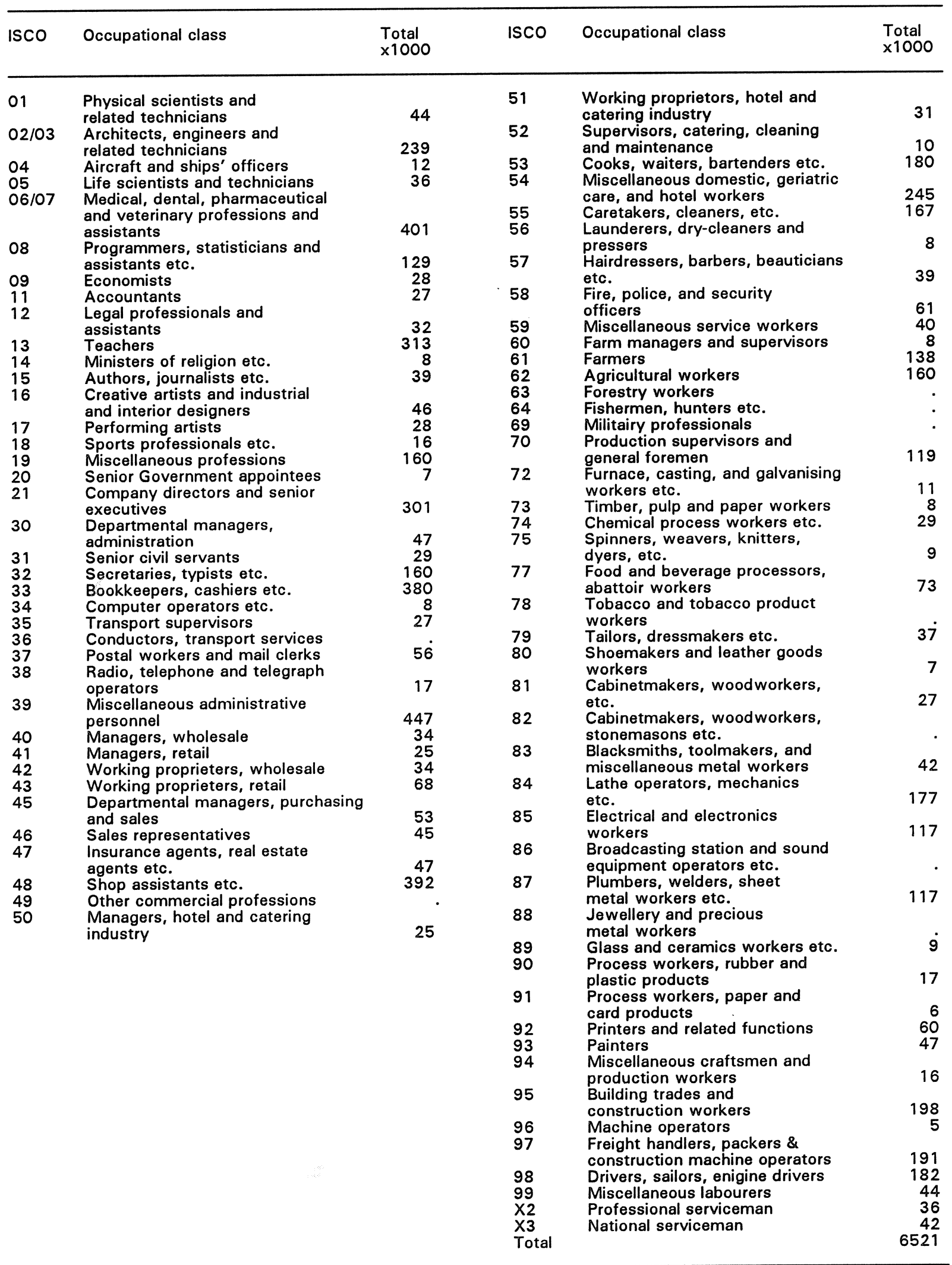


Table 2. Working population by level of education 1991

$\begin{array}{ll}\text { Level of education } & \times 1000\end{array}$

Primary Education

Lower General Secondary Education

Lower Vocational Education

Higher General Secondary Education

Intermediate Vocational Education

Higher Vocational Education

Academic Education

Total

Source: CBS

Table 3. Unemployment by level of education 1991

\begin{tabular}{lcc} 
Level of education & $\begin{array}{c}\text { unemployment } \\
\times 1000\end{array}$ & $\begin{array}{c}\text { unemployment } \\
\%\end{array}$ \\
\hline $\begin{array}{l}\text { Primary Education } \\
\text { Lower General Secondary Education/ } \\
\text { Lower Vocational Education }\end{array}$ & 95 & 11 \\
$\begin{array}{l}\text { Higher General Secondary Education/ } \\
\text { Intermediate Vocational Education } \\
\text { Higher Education* }\end{array}$ & 88 & 5 \\
Total & 93 & 3 \\
\hline
\end{tabular}

* covers Higher Vocational Education and Academic Education (see tables 2 and 4).

Source: CBS

Table 4. Vacancies by level of education 1991

Level of education

$\times 1000$

\section{2}

Primary Education

Lower General Secondary Education

Lower Vocational Education

Higher General Secondary Education

Intermediate Vocational Education

Higher Vocational Education

Academic Education

Total
14.9

26.3

2.3

25.1

9.4

1.9

86.5 vacancies
$\%$

hard to fulfil $\%$

\section{Source: CBS}




\section{FORECASTS OF THE LABOUR MARKET AND THE USE OF LABOUR MARKET MODELS}

The Central Planning Bureau (CPB) is the most important institute making economic forecasts for the Netherlands. In 1990 the CPB developed a multisectoral model for the Netherlands, called Athena (see CPB, 1990). We quote from the abstract of this study: "In the model the private sector is divided into fourteen branches of industry, including agriculture, different branches of manufacturing, construction, mining, energy and different types of services. The public sector and the social security are described by the model as well. (...) The model is intended to be used in forecasting and policy analysis. It has been used in preparing the most recent medium term economic forecast of the Central Planning Bureau and in studies regarding the effects of the completion of the Common Market, and the economic effects of alternative strategies for environmental policy. A modified version of the model will be used in drawing up long term economic scenarios for the Netherlands."

Recently the CPB finished the extensive research project on a long term study of the world economy and the Dutch economy in particular (see respectively CPB, 1992a and CPB, 1992b). The time horizon of this study is 1990-2015. The aim of the study is not to forecast the future economy, but "to help people imagine the various futures which may unfold, while enabling them to better prepare themselves for bottlenecks and opportunities which could emerge" (CPB, $1992 a$, p. 14). To that end the CPB developed four scenarios for the world economy.

In the Global Shift scenario the world economy shifts in favour of the Asian economies. The scenario of European Renaissance is less dynamic than the Global shift. In this scenario Western Europe develops very favourably. The hopes held for Europe '92 are completely fulfilled and the EMU is launched. Although the CPB consciously does not use the terminology, the European Renaissance can be seen as the 'middle scenario'. The third scenario is Global Crisis. In this scenario there will be a deep economic recession. The trends of the 1980 s will continue and the high expectations of Europe '92 will not be met. Finally, the Balanced Growth scenario will bring the world to a long-lasting and multipolar economic growth with balanced markets. Balanced Growth is the most optimistic scenario.

As part of the long term scenario study, projections of the Dutch labour market by level of education are made ${ }^{1}$ (see table 5). In the Global Shift scenario there will be a surplus of workers with lower and intermediate education, excepting intermediate education in the services. For those with higher education unemployment will be at frictional level. In the scenario of Balanced Growth all markets, thus including the labour market, will be in perfect equilibrium: there will be no unemployment for all types of education. In the European Renaissance scenario there are shortages of those with higher education in technical specialities and in services and also of those with intermediate technical education. For the lower types of

1. For the Netherlands the Global Crisis scenario has not been included. 
education a surplus is expected in 2015 under this scenario.

Table 5. Surpluses and shortages on the labour market $1990-2015$ by type of education

\begin{tabular}{|c|c|c|c|c|c|c|c|}
\hline Level of education & 1990 & GS & $\begin{array}{l}2005 \\
\text { BG }\end{array}$ & EUR & GS & $\begin{array}{l}2015 \\
\text { BG }\end{array}$ & EUR \\
\hline Primary Education & ++ & ++ & + & + & ++ & 0 & + \\
\hline $\begin{array}{l}\text { Lower Education } \\
\text { - general/economic } \\
\text { - technical } \\
\text { - services }\end{array}$ & $\begin{array}{l}+ \\
+ \\
+\end{array}$ & $\begin{array}{l}++ \\
++ \\
++\end{array}$ & $\begin{array}{l}+ \\
+ \\
+\end{array}$ & $\begin{array}{l}+ \\
+ \\
+\end{array}$ & $\begin{array}{l}+ \\
+ \\
+\end{array}$ & $\begin{array}{l}0 \\
0 \\
0\end{array}$ & $\begin{array}{l}+ \\
0 /+ \\
+\end{array}$ \\
\hline $\begin{array}{l}\text { Intermediate Educat } \\
\text { - general } \\
\text { - technical } \\
\text { - economic } \\
\text { - services }\end{array}$ & $\begin{array}{l}+ \\
0 \\
0 \\
0\end{array}$ & $\begin{array}{l}++ \\
+ \\
+ \\
+\end{array}$ & $\begin{array}{l}+ \\
0 \\
0 \\
+\end{array}$ & $\begin{array}{l}+ \\
-10 \\
0 /+ \\
0\end{array}$ & $\begin{array}{l}+ \\
+ \\
+ \\
0\end{array}$ & $\begin{array}{l}0 \\
0 \\
0 \\
0\end{array}$ & $\begin{array}{l}+ \\
- \\
0 \\
0\end{array}$ \\
\hline $\begin{array}{l}\text { Higher Education } \\
\text { - technical } \\
\text { - economic } \\
\text { - services }\end{array}$ & $\begin{array}{l}0 \\
0 \\
+\end{array}$ & $\begin{array}{l}0 /+ \\
+ \\
+\end{array}$ & $\begin{array}{l}0 \\
0 \\
0 /+\end{array}$ & $\begin{array}{l}0 \\
0 \\
0 /+\end{array}$ & $\begin{array}{l}0 \\
0 \\
0\end{array}$ & $\begin{array}{l}0 \\
0 \\
0\end{array}$ & $\begin{array}{l}- \\
0 \\
-\end{array}$ \\
\hline $\begin{aligned} \text { GS } & =\text { Global Shif } \\
\text { BG } & =\text { Balanced } \\
\text { EUR } & =\text { European }\end{aligned}$ & $\begin{array}{l}\text { irio } \\
\text { scenario }\end{array}$ & & & & & & \\
\hline
\end{tabular}

Source: $\mathrm{CPB}$

The Research Centre for Education and the Labour Market (Dutch abbreviation ROA), part of the Faculty of Economic Sciences of the University of Limburg at Maastricht, has developed the Information System on Education and the Labour Market (see e.g. Heijke and De Grip, 1991). The system provides three types of information about the relation of education to the labour market:

- various statistical data with regard to the current situation ${ }^{2}$;

- risk indicators relating to the cyclical sensitivity of employment prospects in the different occupational classes and the possibilities of switching to another occupation /lateral movements) or another economic sector (inter-sectoral mobility), indicating the labour market flexibility of the type of education concerned;

- medium term forecasts (over a period of about five years) of both labour demand and supply. At the moment the data in the system is categorised into 93 occupational classes and 49 types of education, covering the entire labour market and the entire educational system.

2. For example data on the structure of employment based on the EBB survey, mentioned in section 1. 
The medium term forecasts of ROA can be divided into (1) forecasts of the level of employment by occupation and education (expansion demand, see for example Dekker et al., 1990, Beekman et al., 1991, Peeters, 1990, and Dekker et al., 1992) ${ }^{3},(2)$ forecasts of replacement demand (see Willems and De Grip, 1990), and (3) forecasts of the flow of school-leavers into the labour market (see Berendsen et al., 1992). When future demand and future supply are correlated an indication of the future labour market situation (IFL) is produced. For the most important results we refer to Van der Velden and Willems (1992).

Besides studies referring to the entire labour market, the ROA also examines the situation on specific labour markets. Examples are studies referring to the labour market for clinical psychologists (see Beekman and Heijke, 1990), the labour market for musicians (see Berendsen and De Grip, 1992), and the labour market for research and development (R\&D) personnel (see Berendsen et al., 1991a and 1991b). The latter study, commissioned by the Dutch Ministery of Economic Affairs, is particularly important for research into the costs of not training. The conclusion of this study is that in the year 2010 there will be a shortage of about 12,000 researchers, which is $12 \%$ of all working researchers at this moment. Such a huge shortage of R\&D workers will inevitably be a bottleneck for the innovation and diffusion potentials of the Dutch economy. Table 6 gives the main results of these forecasts.

Table 6. Supply surpluses and shortages for researchers, as percentages of the expected average numbers of researchers employed, by educational type, 1990-2010

\begin{tabular}{lcccc}
\hline Educational type & $\begin{array}{c}1990-1995 \\
\%\end{array}$ & $\begin{array}{c}1996-2000 \\
\%\end{array}$ & $\begin{array}{c}2001-2005 \\
\%\end{array}$ & $\begin{array}{c}2006-2010 \\
\%\end{array}$ \\
\hline $\begin{array}{l}\text { Academic education } \\
\text { of which: }\end{array}$ & -2 & -7 & -8 & -11 \\
$\begin{array}{l}\text { Agricultural sciences } \\
\text { Mathematics and natural sciences }\end{array}$ & -14 & 15 & 10 & 6 \\
Technical sciences & 6 & -20 & -20 & -22 \\
Medical sciences & -7 & 3 & -0 & -9 \\
Higher vocational education & -8 & -9 & -8 & -16 \\
Secondary education & -17 & -14 & -14 & -20 \\
\hline
\end{tabular}

Source: ROA

Another labour market segment for which supply shortages are forecast is the labour market for primary school teachers. There are also expected shortages in some parts of the labour market for secondary school teachers (see IVA, 1992). Furthermore shortages are expected for nurses (see Gerritse and Van der Windt, 1991). Other studies refer to the labour market in the health care sector (see Vissers et al., 1992) and the labour market for environmentalists (see Netherlands Economic Institute, 1988). Finally Lodder et al., (1992) describe the inflow and outflow on the market for apprenticeships.

3. The ROA expansion demand forecasts for occupations and types of education are based on and therefore consistent with the CPB forecasts for the economic sectors. 


\section{TRAINING ACTIVITIES}

In this section we will present some of the recent research into the training activities of employees. First we will discuss the most important databases on (continous) training activities ${ }^{4}$. Then some studies in the training field will be reviewed, especially with regard to the effects of training. We do not focus on the various evaluation studies with regard to training schemes for the unemployed (see e.g. De Koning et al., 1990).

\section{Databases with regard to training}

The first main data source in the training field is the Company Training Survey of the CBS held in 1986 (see CBS, 1988). The structure of the survey is as follows: out of a population of 73,000 firms, 24,000 firms are selected for a pre-survey to establish whether a company is active in the field of training. In a second step approximately 5,000 companies, excluding the public sector, with more than 5 employers were surveyed. The survey has been repeated in 1991.

From the companies included in the survey it is known how many employees took part in internal or external training courses. Training-related items such as the objectives, duration, and level of the training are also known. The company-related items are the economic sector, the number of employees, training facilities, and the total expenses of training. Employee-related items are gender and working time (full-time versus part-time). See Brandsma et al. (1992) for more details on the results of this survey.

The Organisation for Labour Market Research (Dutch abbreviation OSA) has set up two important databases for labour market research, both having a panel character. The first data panel - the OSA Labour Supply Survey - is based on a survey of approximately 4,000 persons between 18 and 65 years old (see Allaart et al., 1991). In Autumn 1990 the fourth round of this survey was held ${ }^{5}$. The OSA database contains many items on various sectors of the labour market. All training after primary school is included (classified using the ISCED), so the level of participation in adult education is known in this survey. We also know whether the courses are initiated by the employing firm (both internal and external training) or attended at personal initiative. Moreover the database contains information on training attendance at the moment of the survey. As was said before, apart from the education variables, the OSA Labour Supply Survey contains a number of other (background) variables, such as gender, age, labour market position, occupation (classified with ISCO), economic sector, firm size etc.

The second database of the OSA is the OSA Labour Demand Survey (see Allaart et al., 1992).

4. Van der Velden and Willems (1991) and Brandsma et al. (1992) give a more extensive overview of the databases on adult education, mentioned here.

5. Earlier rounds were in Spring 1985, Autumn 1986 and Autumn 1988. 
This survey, among approximately 2,000 organisations with more than 10 employees, including the public sector, has been carried out in Spring 1989 and 1991. The responding firms, including the public sector, have been asked what proportion of their employees have attended internal and/or external education. The survey gives information on the level, direction, and duration of the training. Furthermore we know a number of company-related items, such as the economic sector, the number of employees, the sex and age profile, the mean educational level of the employees, etc. Other important information in this database is the total number of vacancies and whether the vacancies are hard to fill (see also section 1).

Two other data sources which we can mention here are the HBO monitor and the RUBS survey, both conducted by ROA together with the National Service Bureau for School Leavers' Information (see respectively Van de Loo et al., 1992 and Lodder et al., 1991). These data sets are based on a survey of approximately 9,000 school-leavers from higher vocational education and approximately 45,000 school-leavers from secondary education, respectively. In these surveys there are some questions on both the need for and the participation in additional training. Furthermore the ROA has started a survey among the graduates of the University of Limburg (see Heijke and Ramaekers, 1992). This survey also contains some information about training activities. Finally, we will mention the Rotterdam Institute for Sociologic and Public Administration Research (Dutch abbreviation RISBO). This institute has several databases on training for the metal working sector. (see Coenegracht et al., 1989).

\section{The effects of training}

In this subsection we will discuss some studies with regard to the effects and causes of training activities. Bekkering et al. (1988) studied the effects of technological advance on the skill requirements for the working population. The analyses take place at the level of economic sectors. The main conclusion is that there is no significant relation between technological advance and the educational level of the working population, although there are some significant effects from two factors, at the expenses of research and development and the percentage of workers in administrive automation (two of the technology indicators used), on the educational structure of employment. But in relation to the effects of shifts in the educational structure of the labour supply (the supply effect) this technology (demand) effect is very small.

The second study with relation to the effects of technology on training we will mention here is the article of Groot and De Grip (1991). This study examines the effects of technological change on skill formation in the banking sector. Contrary to the study of Bekkering et al., they do find significant effects. We quote from the abstract: "A cross-section analysis of 100 local banks shows that the diffusion of office automation has significant positive effects on both the skill level and the share of vocationally skilled workers. The results also show that the automated banks use recruitment policies more intensively than less automated banks in adjusting the skill structure." A reason for the differences in the results between Bekkering et al. and Groot and De Grip can be found in the fact that the latter could make use of a much 
more detailed dataset. Other studies referring to the effects of technology on the occupational and educational structure are Dekker et al. (1990) and Beekman et al. (1991). De Grip et al. (1992) focus on the relation between training processes and mobility patterns on the labour market.

Recently the Netherlands Economic Institute (NEI) has published two reports on the relation between age, labour productivity, and earnings (see De Koning et al., 1991 and Gelderblom and De Koning, 1992, or the papers in English based on these studies: De Koning and Gelderblom 1992a and 1992b). The first study focuses on the goals and effects of company training and asks whether company training programmes achieve their principal target of increasing productivity and the related question of whether the opportunities offered by company training programmes are already exploited in full or if there is underinvestment.

The results show that firms' labour productivity has a significant effect on the degree of training (see table 7). However according to this study the training effort has no significant effect on firms' productivity (see table 8).

Table 7. Regression results of the equation for the training degree with computed productivity

\begin{tabular}{||l|c|c|c||}
\hline & $\begin{array}{c}\text { Regression } \\
\text { coefficient }\end{array}$ & T-value & $\begin{array}{c}\text { Original } \\
\text { regr.coeff. }\end{array}$ \\
\hline Productivity & 7.50 & 1.83 & $(7.35)$ \\
Proportion of employees in & 0.57 & 1.79 & $(0.57)$ \\
permanent employ & 0.35 & 1.98 & $(0.35)$ \\
Proportion of staff under 30 & -0.89 & -3.72 & $(-0.89)$ \\
Proportion of executive staff & 2.86 & 2.08 & $(2.88)$ \\
$\begin{array}{l}\text { Hours spent on organisation } \\
\text { of training programmes per } \\
\text { labour year }\end{array}$ & 15.84 & 2.74 & $(15.90)$ \\
$\begin{array}{l}\text { Training strategy geared to } \\
\text { personnel management }\end{array}$ & -17.21 & -0.40 & $(-16.40)$ \\
Constant & 0.56 & & $(0.57)$ \\
\hline $\begin{array}{l}\text { Corrected correlation } \\
\left.\text { coefficient (R }{ }^{2}\right)\end{array}$ & & & \\
\hline
\end{tabular}

Source: De Koning and Gelderblom (1992a)

In the second study the relation between labour productivity and wages on the one hand and training intensity of the workers on the other hand has been examined on the basis of the OSA Labour demand survey. One of the main questions is: "Can training improve productivity while on the same time leaving wages relatively stable?" (De Koning and Gelderblom, 1992b, p. 7). Their conclusion is that the effects of training on productivity exceed the effects on wages (see also figure 1). The graph shows that the productivity curve moves up much further than the wage curve when participation in internal and external training increases by 10 percentage 
points, while the other explanatory variables remain fixed. However it has to be pointed out that the authors note some reservations about some assumptions made in the analysis, such as not taking into account the costs of training and the causality of the relation between productivity and training (compare De Koning and Gelderblom, 1992a).

Table 8. Regression results of the equation for productivity with computed training degree

\begin{tabular}{|c|c|c|c|}
\hline & $\begin{array}{l}\text { Regression } \\
\text { coefficient }\end{array}$ & T-value & $\begin{array}{l}\text { Original } \\
\text { regr.coeff. }\end{array}$ \\
\hline Training degree & 0.0027 & 0.53 & $(0.0043)$ \\
\hline Staff's automation degree & 0.015 & 2.96 & $(0.014)$ \\
\hline Size of staff in man-years & 0.00045 & 3.25 & $(0.00044)$ \\
\hline $\begin{array}{l}\text { Demands for training } \\
\text { recorded }\end{array}$ & 0.23 & 1.30 & $(0.22)$ \\
\hline $\begin{array}{l}\text { Dummy variable for the } \\
\text { machine-industry sector }\end{array}$ & -0.45 & -2.24 & $(-0.46)$ \\
\hline $\begin{array}{l}\text { Dummy variable for the } \\
\text { transport sector }\end{array}$ & 0.39 & 1.79 & (0.39) \\
\hline $\begin{array}{l}\text { Dummy variable for the } \\
\text { insurance sector }\end{array}$ & 0.45 & 1.21 & $(0.43)$ \\
\hline Constant & 4.24 & 27.22 & $(4.22)$ \\
\hline $\begin{array}{l}\text { Corrected correlation } \\
\text { coefficient }\left(R^{2}\right)\end{array}$ & 0.71 & & $(0.72)$ \\
\hline
\end{tabular}

Source: De Koning and Gelderblom (1992a)

Figure 1. Effect of increasing training

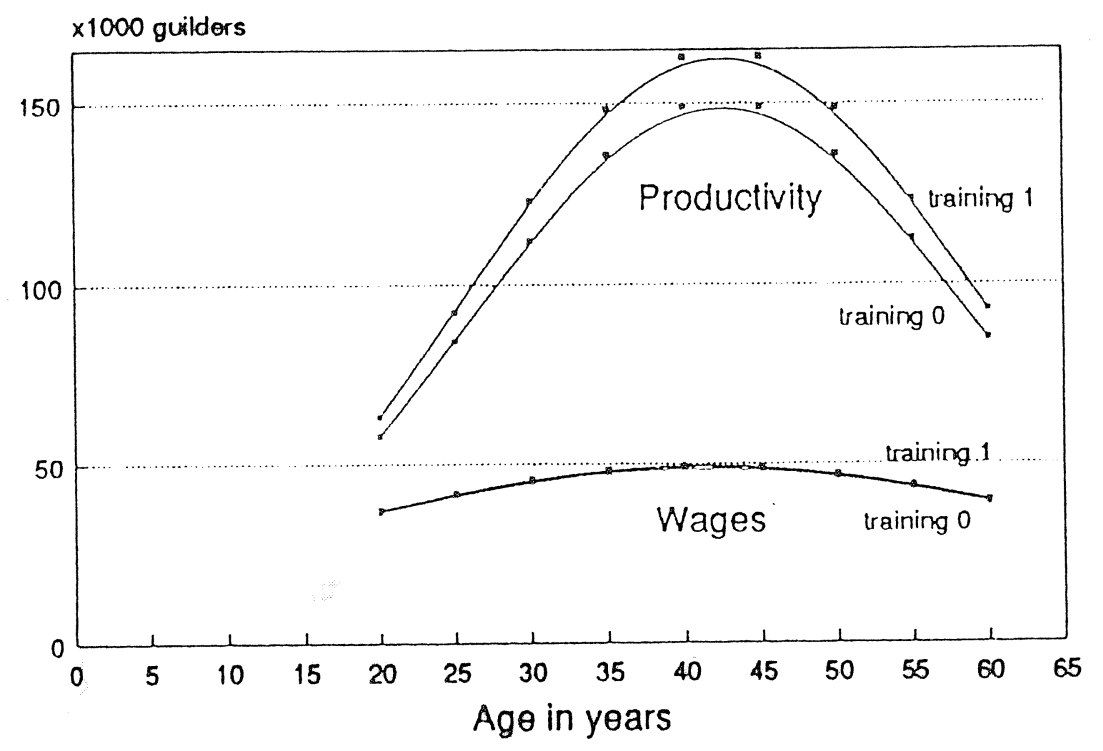

Source: De Koning and Gelderblom (1992b) 


\section{SOME CONCLUSIONS}

From this inventory of training studies undertaken in the Netherlands some tentative conclusions may be drawn. Generally speaking it is not clear what the exact purposes of most training activities are. Some training activities aim at closing the gap between the skill profile of the workers and occupational profiles which are being changed by technological and organizational developments. Others focus on improving the productivity level of the workers and for optimizing their career patterns in the firm or the profession. A third category of training -although paid by the firm- has no clear economic purpose, but can be compared with (other) fringe benefits that have some wage compensating character.

For new studies on training activities it is therefore important to define carefully the specific characteristics of the kind of training to be analised and to find out in advance what possible purposes could lead to the initiation of these training activities. In order to trace the real effects of the level of training a suitable analytical framework has to be chosen. This framework will depend on the training purposes considered, and several kinds of analysis may be relevant: a traditional discrepancy analysis of supply and demand is suitable for training activities in occupational markets, whereas an analysis of the productivity developments and mobility patterns on internal labour markets or extended professional markets requires other methods. Finally it is possible that the appropriate framework for the study, given the type of training concerned, is the (compensating) wage policy of employers as a specific element of their implicit contracting or efficient wage policy.

It is obvious that, due to the aging of the workforce and rapid technological developments, continuous training will become more and more important. Moreover, in addition to the skill level of workers, the vocational character of initial education and the field of study will also be of great importance. In particular with regard to the technical trades and professions, both initial education and training should play a crucial role in combatting labour supply shortages, in both a quantitative and a qualitative sense. Another field of interest will be training in commercial and language skills, due to the increasing importance of the quality of services and the globalisation of the economy. 


\section{REFERENCES}

Allaart, P.C., W.C.M. Praat, J.P.M. Vosse (1992), Trendrapport vraag naar arbeid 1992 (Trend Report Demand for Labour 1992), OSA-rapport no. 16, Den Haag.

Allaart, P.C., R. Kunnen, W.C.M. Praat, H.A. Van Stiphout, J.P. Vosse (1991), Trendrapport aanbod van arbeid 1991 (Trend Report Supply of Labour 1991), OSA-rapport no. 12, Den Haag.

Beekman, T., R. Dekker, A. De Grip, H. Heijke (1991), An Explanation of the Educational Structure of Occupations, Labour, vol. 5, no. 3, pp. 151-163.

Beekman, Th.B.J., J.A.M. Heijke (1990), De arbeidsmarktperspectieven voor klinisch psychologen tot 1995 (The Labour Market Prospects for Clinical Psychologists to 1995), ROAR-1990/3, Maastricht.

Bekkering, J.M., J.S. Cramer, I.A.M. Oud (1988), Technologie en opleidingseisen (Technology and Training Requirements), SEO rapport no. 214, Amsterdam.

Berendsen, H., A. De Grip (1992), De actuele en toekomstige arbeidsmarktpositie voor musici; haalbaarheidsonderzoek (The Actual and Future Labour Market Position for Musicians; Feasibility Study), ROA-R-1992/6, Maastricht.

Berendsen, H., A. De Grip, E.J.T.A. Willems (1991a), De toekomstige arbeidsmarkt voor onderzoekers 1990-2010 (The Future Labour Market for Researchers 1990-2010), Ministerie van Economische Zaken, Beleidsstudies Technologie Economie no. 13, Den Haag.

Berendsen, H., A De Grip, E.J.T.A. Willems (1991b), The Labour Market for R\&D Manpower in the Netherlands, Paper presented at the Third Conference of the European Association of Labour Economists (EALE), El Escorial, Spain, September 26th-29th.

Berendsen, H., R.J.P. Dekker, A. De Grip, P.J.E. Van de Loo (1992), Prognose arbeidsmarktinstroom van schoolverlaters per opleidingstype (Forecast of Labour Market Inflow of Schoolleavers by Type of Education), ROA-W-1992/2, Maastricht.

Brandsma, T.F., J.W. Van Dam, A. De Grip (1992), Continuing Vocational Training in the Netherlands; Managing Chart, OCTO/ROA, Enschede/Maastricht.

Central Bureau of Statistics (1988), Bedrijfsopleidingen in Nederland 1986 (Company Training in the Netherlands 1986), Staatsuitgeverij, Den Haag.

Central Planning Bureau (1990), Athena; Een bedrijfstakkenmodel voor de Nederlandse economie (Athena: A Multisectoral Model for the Dutch Economy), Monograph no. 30, Den Haag. 
Central Planning Bureau (1992a), Scanning the Future; A Long-term Scenario Study of the World Economy 1990-2015, SDU Publishers, The Hague.

Central Planning Bureau (1992b), Nederland in drievoud; Een scenariostudie van de Nederlandse economie 1990-2015 (The Netherlands in triplicat; A Scenario Study of the Dutch Economy 1990-2015), SDU Uitgeverij, Den Haag.

Coenegracht, A.M.M.A., S.C.A. Kole, J.R.L. Steijvers (1989), Onderwijs en vakmanschap; Een onderzoek naar de kwalitatieve en kwantitatieve aans/uiting van het leerlingwezen, KMBO en $M B O$ op de branches metaalbewerking en installatietechniek (Education and Craftsmanship: A Research into the Qualitative and Quantitative Match between the Apprenticeship System and Shorter and Intermediate Vocational Education and the Industrial sectors Metal Working and Installation, RISBO, Rotterdam.

De Grip, A. (1986), Winnaars en verliezers op de arbeidsmarkt in de jaren '70 (Winners and Losers on the Labour Market in the 1970s), Tijdschrift voor arbeidsvraagstukken, vol. 2, no. 1, pp. 41-51.

De Grip, A. (1987), Winnaars en verliezers op de arbeidsmarkt 1981-1985 (Winners and Losers on the Labour Market 1981-1985), Tijdschrift voor arbeidsvraagstukken, vol. 3, no. 4, pp. 6169.

De Grip, A., R. Dekker (1993), Winnaars en verliezers op de arbeidsmarkt 1985-1990 (Winners and Losers on the Labour Market 1985-1990), forthcoming.

De Grip, A., J.A.M. Heijke, E.J.T.A. Willems (1992), Scholing en mobiliteit (Training and Mobility), Maandschrift Economie, vol. 56, pp. 131-144.

De Koning, J.M. Koss, A. Verkaik (1990), A Quasi-Experimental Evaluation of the Vocational Training Centre for Adults, Paper for the second EALE Conference, Lund, September 20th-23th.

De Koning, J., A. Gelderblom (1992a), Company Training: Volume, Underinvestment and Return, Paper for the fourth EALE Conference, Warwick, September 3th-6th.

De Koning, J., A. Gelderblom (1992b), Age, Productivity and Wages, Paper for the fourth EALE Conference, Warwick, September 3th-6th.

De Koning, J. A. Gelderblom, A. Hammink, R. Olieman (1991), Bedrijfsopleidingen: omvang, aard verdeling en effecten (Company Training: Volume, Character, Division and Effects), RVE/NEI, Rotterdam.

Dekker, R., A. De Grip, H. Heijke (1990), An Explanation of the Occupational Structure of Sectors of Industry, Labour, vol. 4, no. 3, pp. 3-31. 
Dekker, R., A. De Grip, J.A.M. Heijke (1992), The ROA Information System for Education and the Labour Market: Models and Methods, Contribution to the Symposium 'Education and the Labour Market: From Research to Policy-Making', May 8th, Maastricht.

Gelderblom, A., J. De Koning (1992), Meer-jarig, minder-waardig? Een onderzoek naar de invloed van leeftijd op produktiviteit en beloning (Increase in Age, Decrease in Value? A Research into the Effect of Age on Productivity and Wages), OSA-voorstudie V39, Den Haag.

Gerritse A.J., W. van der Windt (1991), Van verloop naar loopbaan; een arbeidsmarktverkenning verpleging en verzorging in de negentiger jaren (From Turnover to Career; an exploratory study of the Labour Market for Nursing and Paramedical Services in the 1990s), Nationaal Ziekenhuisinstituut, Utrecht.

Groot, L.F.M., A. De Grip (1991), Technological Change and Skill Formation in the Bank Sector, Economics of Education Review, vol. 10, no. 1, pp. 57-71.

Heijke, J.A.M., A. De Grip (1991), The Information System on Education and the Labour Market Developed by ROA, ROA-W-1991/2E, Maastricht.

Heijke J.A.M., G.W.M. Ramaekers (1992), Labour Market Position of University of Limburg Graduates, ROA-RM-1992/2E, Maastricht.

IVA, Institute for Social Research (1992) Verbeterde arbeidsmarktramingen voor leraren in het primair en voortgezet onderwijs, (Improved Labour Market Projections for Primary and Secondary School Teachers), IVA, Tilburg.

Lodder B.J.H., A. De Grip, J.A.M. Heijke (1992), In- en uitstroom op de markt voor leerovereenkomsten (Inflow and Outflow in the Market for Apprenticeships, ROA-RM-1992/1, Maastricht.

Lodder, B.J.H., G.W.M. Ramaekers, R.K.W. Van der Velden (1991), De arbeidsmarktpositie van schoolverlaters van het economisch en administratief (K)MBO; RUBS '91 (The Labour Market Position of School-leavers from Shorter and Intermediate Vocational Education in Commerce and Administration; RUBS '91), ROA-R-1991/11, Maastricht.

Netherlands Economic Institute (1988), Behoefte aan kennis op milieugebied: een verkenning van de arbeidsmarkt voor milieudeskundigen, (The Need for Knowledge about the Environment; An Exploratory Study of the Labour Market for Environmentalists), NEI, Rotterdam.

Peeters, H.M.M. (1990), An Explanation of the Occupational and Educational Structure of Employment by Means of Multinomial Logit, ROA-W-1990/4E, Maastricht. 
Van de Loo, P.J.E., G.W.M. Ramaekers, R.K.W. Van der Velden (1992), De arbeidsmarktpositie van afgestudeerden van het hoger beroepsonderwijs 1991 (The Labour Market Position of Graduates from Higher Vocational Education 1991), Voorlichtingsdienst HBO-raad, Den Haag.

Van der Velden, R.K.W., E.J.T.A. Willems (1991), Volwasseneneducatie; Een inventarisatie van bestaande databestanden (Adult Education; An Inventory of Existing Databases), ROA-W1991/4, Maastricht.

Van der Velden, R.K.W., E.J.T.A. Willems (1992), The Market Position of Occupations and Types of Education, Contribution to the Symposium 'Education and the Labour Market: From Research to Policy-Making', May 8th, Maastricht.

Vissers, A.M.C., G.H.M. Evers, M.H.L. Van Tits, H. Vermeulen, R.W. Euwals (1991), De ontwikkeling op de arbeidsmarkt in de zorgsector tot het jaar 2000 (Developments in the Labour Market in the Health Care Sector to the Year 2000), IVA, Tilburg.

Willems, E.J.T.A., A. De Grip (1990), Replacement Demand Forecasts by Occupation and Education, ROA-W-1990/7E, Maastricht. 